\title{
From ordinary environmentalism to the public environment: theoretical reflections based on French and European empirical research
}

Nathalie Blanc ${ }^{1}$

\begin{abstract}
Ecological transformations involve citizen mobilization and the cultural transformation of relationships with the environment. Rather than social movements, we need to see them more as social-environmental communities. They are formed through joint action on the material environment, underpinned by solidarity and conflicts of territoriality in which human collectives associate with living matter and the environment to battle other uses of space. The environment as a collective work then becomes a self-sustaining basis for action that boosts the competence and legitimacy of the actors (citizens, formal and informal collectives, etc.) and their role in social-ecological transition. We thus witness the emergence of a new type of environmental citizenship that deviates from political activism and testifies to a civic engagement in ordinary practices, a collective environmentalism that calls for public action and democracy. Our hypothesis is that ordinary environmentalism initiatives contribute to the production of a public environment, i.e., an environment that we may qualify as public insofar as urban citizen environmentalism contributes to the public space both in terms of debates and in a concrete manner. What we call ordinary environmentalism factors in environmental practices that have hitherto been considered negligible and emphasizes their usefulness in democratizing the coproduction of everyday and ordinary environments. We need to view the emergence of ordinary environmentalism in relation to distributions and inequalities in territories from an environmental and physical, as well as from a social, point of view or from the perspective of political commitment.
\end{abstract}

Key Words: commons; ordinary environmentalism; public environment; urban ecology

\section{INTRODUCTION}

Metropolitan dynamics have been characterized by an increased level of civic engagement vis-à-vis the environment itself and the living environment through established structures (associations, federations, etc.) or more labile forms (ad hoc collectives, informal groups, coalitions, etc.). Research into "environmental stewardship" or "civic environmentalism" has highlighted the renewed vigor of civil society (Blanc and Emelianoff 2008, Paddeu 2017) and the diversity of forms of engagement (Cefaï 2009, Krasny and Tidball 2012). Much of this research has focused on commitment at the level of a neighborhood or sector of activity, such as energy autonomy (Emelianoff 2018) or urban agriculture (Darly 2012, Darly et al. 2013).

Beyond these issues, civic engagement vis-à-vis the environment has been widely discussed in articles and books, some focused on ordinary environmentalism and others on the collective learning of bottom-up democracy (Meyer 2015, Meyer and Kersten 2016, Schlosberg and Coles 2016, Schlosberg 2019). The focus concerns the way in which democratic forces are created, i.e., a collective desire for common rules of living. Lepori (2019) discusses the relationship between a deliberative ecological democracy and the need for a democratic policy based on collective mobilizations born in response to the problems associated with ordinary living conditions, low-priced housing, better education, and environmental quality, etc. Many of these mobilizations also concern renewed forms of consumption, or, conversely, opposition to the dominant modes of consumption. The history of social movements teaches us that there are both opposition movements to the forms of dominant power and movements that support forms of self-organization at the local level. Mutualist and cooperative movements figure among the latter, and they appeared and developed during the first half of the 19th century (Forno and Graziano 2014).
Furthermore, scientists have analyzed the governance arrangements that bring together stakeholders from the public sector and civil society (Sirianni and Friedland 2001, Andrews and Edwards 2005), notably qualifying such arrangements as hybrid (Fisher and Svendsen 2014), "DIY" (Blanc et al. 2017), or mosaics (Buijs et al. 2016).

Research has also focused on the social-ecological transformative scope of collective initiatives (Agyeman and Briony 2003, Barthel et al. 2010, Westley et al. 2013) beyond neoliberalism (Springer 2016). However, early results in France highlight associationbased initiatives that are too few and insufficiently structured to effect a major transformation of environments on a socialecological basis (Blanc et al. 2017).

One of the key debates is how civic engagement vis-à-vis the environment can be synonymous with the renewal of politics from a reengagement and a rearrangement of the related material flows. Scholsberg and Coles (2016) put forward this new way of reading social movements by repositioning of material flows that a justicebased framework does not take into account. The collective mobilizations testify moreover to a renewed engagement with the material quality of the places. It is not just a matter of proximity, but concerns the ability to arrange new material flows, e.g., food or even biodiversity, creating hospitable places for species. The geographer Stacy Alaimo (2016: 120) argues : "Activists, as well as everyday practitioners of environmental, environmental health, environmental justice, and climate change movements, work to reveal and reshape the flows of material agencies across regions, environments, animal bodies, and human bodies - even as global capitalism and the medical-industrial complex reassert a more convenient ideology of solidly bounded, individual consumers and benign, discrete products." Among the new materialist thinkers (Braidotti 2002, Barad 2007, Alaimo 2010, 2016, Bennett 2010, Coole and Frost 2010), Alaimo offers one 
reading of the activists' exchanges with built and natural elements of the environment that they preserve, protect, and defend. According to this author, the determinants of collective action are situated within a history and a geography that tends to reproduce them as well as to favor their metamorphoses. In terms of a critical approach to urban research, this positioning makes it possible to construct a multidimensional and multiscalar perspective of the power relations between the agents, be they living beings or things, such as food in the production of short circuits, for example.

\section{Issues tackled}

This paper seeks to extend these analyses and examine the role of civic urban environmentalism at metropolitan and intersectoral levels. These collective approaches qualified as ordinary environmentalism (Blanc and Paddeu 2018) are presented from an apolitical perspective based around frequently banal day-today environmental concerns and practices: air and water quality, urban sprawl, urban agriculture, protection of biodiversity, preservation of parks and forests, waste management and recycling, energy transition, food consumption patterns, etc. Born out of investments in the public space based on personal or collective needs (i.e., recreational, food, nature-related, social) (Torres et al. 2017), the collectives primarily carry out local work to preserve, manage, monitor, advocate for rights, and/or educate on the local environment and quality of urban life (Svendsen and Campbell 2008, Fisher et al. 2012).

Moreover, despite the modest and banal nature of their actions, these groups collectively construct the meaning of places and influence the development of local communities based on alliances with elements of the environment that confer them with a political nature. Folke et al. (2016: 41) write: "the coevolutionnary development of people and nature needs to be studied." As such, the forging of alliances between groups and elements of the environment proceeds from the meaning attributed to places. Conversely, this meaning is the product of the action of collectives (Enqvist et al. 2017: 157). The history of the places is thus constructed in situ and is based on "lived worlds" (Gorz 1968, as cited in Petit and Guillaume 2016: 63).

This article seeks not to revisit findings concerning ordinary environmentalism that have already been published (Blanc and Paddeu 2018) but to conduct a more indepth analysis of relations between the initiatives taken by these actors and the collective and negotiated production of the public environment. We contend that ordinary environmentalism initiatives actually contribute to the production of a public environment, i.e., an environment that we may qualify as public insofar as urban citizen environmentalism contributes to the public space both in terms of debates and in a concrete manner. The environment, in the sense of a social-ecological system, is generally the product of collective activity in various places and fits firmly into political and administrative spaces (Chapin et al. 2010). Rather than just privatization of space, we may speak of the dynamics of the contribution of ordinary environmentalism to the socialecological quality of public spaces in the general interest. The term social-ecological system (Folke and Gunderson 2012, Folke et al. 2016) therefore appears appropriate for describing the ways in which these activist practices make a positive contribution to living habitats (Torres et al. 2017). Much research has already focused on the possible instrumentation and instrumentalization of "stewardship" practices. Attachment to the local environment may be seen as a lever for local governments via communitarization practices (Rose 1996), however, we wish to explore their contribution to the political sphere by elaborating on the expression of public environment. As such, the idea is to examine it within the context of environmental justice, which focuses on attachment to local living conditions and ordinary practices in what is sometimes termed "everyday environmentalism" (Agyeman et al. 2016).

Moreover, the empirical research presented in this article attempts to redeploy a reading of the agentivities at work by questioning urban environments from the perspective of a multiplicity of actors. K. Barad (2016) and R. Braidotti (2002) both argue for a renewed understanding of subjectivity. In short, the new materialist thinkers highlight the differences between a sociospatial structure as the product of social practices and a sociospatial structure that supports a variety of material configurations of exchange. We should also insist on the routine character of collective action in the sense that it takes shape and develops at every moment drawing on various understandings of structural and structuring dynamics (Welch and Yates 2018). We argue here that the term public environment may qualify renewed local material arrangements as the new form of expression of the political, beyond the "logocentrism" apparent in representative democracies.

We will develop this article in several sections. A first part is dedicated to observations collected from case studies. We will try to deploy the conceptual expression of public environment alongside four subthemes. It primarily concerns the questions of "assemblages" or alliances between human beings and elements with natural characteristics of their environment. Secondly, it is important to look at the impact of ordinary environmentalism initiatives on lives locally. Then, we will explore the ecological importance of these small social movements. Finally, we will consider the role of these initiatives as an instrument of public action sometimes assuming a mission of general interest or a delegation of public service.

A second section will take the form of a discussion. We will defend the idea that the development of civic environmentalism is based on the activation of local alliances and a renewed way of experimenting in urban spaces. The stewardship groups produce places and services, sometimes treated as commons, that are part of the production of a public environment. It is therefore a question of explaining and theorizing how groups and associations contribute to the public space, both as a symbolic and a concrete space.

\section{METHODS}

As part of this research, we devised a survey of local associations and environmental collectives - leaving aside national associations (such as the nature defence associations Amis de la Terre, France Nature environnement, Ligue de Protection des Oiseaux, etc.) and international organizations and foundations (like WWF, Greenpeace, Fondation de France, etc.) - active within the Grand Paris project. (The Métropole du Grand Paris was set up on 1 January 2016 under the 27 January 2014 Law to modernize public action and reaffirm cities (MAPTAM Law), strengthened by the 7 August 2015 Law focusing on the new organizational structure 
of the French Republic (NOTRe Law). It comprises 131 municipalities including the City of Paris.) Cutting across the different sectors of associative environmentalism, the recent draft CIVIC ACT aims to provide a spatialized overview of ordinary environmentalism - over and above a sector of activity or specific collectives - at metropolitan Greater Paris scale. Métropole du Grand Paris, a publicly owned regional body created on 1 January 2016, comprised 6,968,051 inhabitants in 2016. The City of Paris represents $32 \%$ of this total, with 2.2 million inhabitants.

The first phase involved devising an investigation method that would reflect the diversity of the municipalities of Grand Paris based around statistical classification and sampling methods. The aim was to select municipalities as future survey locations with sufficient qualities and quantities to be able to sustain a campaign of interviews whose findings would be representative of the territorial diversity of Grand Paris. The creation of a database of the 131 Grand Paris municipalities was based on a description, municipality by municipality, of land occupancy, including exposure to pollutants (metals) (environmental variables), socioeconomic and demographic composition based on census data (socioeconomic and demographic variables), the results of all elections organized since 2001 (political variables), and the number of environmental associations registered with the "Préfecture" (associative variable). For this last variable, the database comprises the list of nonprofits ("associations 1901") in the 131 municipalities of Greater Paris provided by the Directorate of Legal and Administrative Information (DILA). However, the difficulties in developing a reliable database make any research on associations in France and in the United States quite tricky (Brulle et al. 2007).

Using this data, we produced a typology of the territories concerned and built a sample of target municipalities with a view to conducting a qualitative survey. We were thus able to conduct a principal component analysis (PCA) on land-use data (MOS database) for the 131 municipalities of Grand Paris. It is this approach to intermunicipal differences based on land use that constitutes the originality of this work to classify the territories of Greater Paris when compared with research based around socioprofessional categories. Lastly, statistical sampling was used to determine the municipalities in which qualitative surveys would be conducted. In the three classes with unequal weighting, 60 municipalities were drawn at random in accordance with the relative weighting of each class. Next, we selected one out of every two municipalities in which there was a sufficient number of environmental associations for conducting qualitative surveys. Within the 31 associations ultimately selected, we systematically contacted all of the environmental associations and conducted semistructured interviews with an active member. This methodology afforded access to a diverse sample of actors, especially more marginal groups within the world of environmental associations.

Fifty-two semistructured interviews were therefore conducted with members with responsibilities in associations or collectives within a sample of 30 representative municipalities from among the 131 municipalities. We were especially interested in individuals committed to collective approaches (associations, collectives, informal groups, coalitions, etc.) underpinned by diverse action and value systems but united by a common denominator, i.e., exploring transformative environmental practices in the milieu(s) they inhabit.

The interview guidelines can be divided into several broad groups of questions: a first group related to the identity of the association being studied ("Tell me about your association"); a second concerning aims: "What is most important to you in carrying out your mission"; a third dealing with the practices of the association: "How do you carry out your mission?"; a fourth on the relationship with the spaces occupied: "How do you look after the places in which you are present?" A fifth covering the networks developed: "Who do you work with/who are your partners?"; a sixth on estimated results: "In your opinion, what are the results/ effects of your actions?"; and a final item covering requirements: "What does your association need? How could the creation of an association platform in Greater Paris and its contribution to local policy making drive things forward?"

The same methodology for analyzing nonautomated content was used to systematically analyze the interviews. This methodology made it possible to reflect the diversity of collectives as well as the manner in which they were embedded in the day-to-day goings on of the municipality and helped anchor environmental issues in urban territories in a multiscalar way in liaison with public bodies. It also highlighted the profiles of respondents who, aside from their diverse professional occupations (webmaster, teacher, concierge, actor, publisher, nun, etc.), were mostly novices in environmental matters. These individuals have frequently moved from environmental leisure pursuits to a collective, sometimes multifaceted engagement.

The CIVIC ACT research program represents an attempt to develop a theory of civic engagement vis-à-vis the environment involving a multiscalar, multiagent materiality in urban spaces beyond merely denouncing the withdrawal of the neoliberal state, both in terms of policies and in ecosociosystemic terms. We thus focus on the ways in which civil society collectives, involving humans, plants, and animals, and a variety of environmental forms (landscapes, shared gardens, rivers, trees, mushrooms, etc.), are able to recover from given conditions in a territory, a history, and a geography, to transform them into a personal history, at the origin of human/nonhuman relations, but also as a source of action at the origin of a multidimensional and multiscalar transformation of social-ecological territories. Thus, the main hypothesis of the work concerns the role of civil society collectives in socioenvironmental inequalities in Greater Paris. The dual investigation concerns both the production of this environment, underpinned by a socioeconomic dynamic, and the way in which the environment places capitalist production in crisis, in particular around mobilizations and urban struggles. From then on, the flows within the material environment become a place for reconquering autonomy, far removed from the processes of deterritorialization specific to capitalisms.

\section{RESULTS}

\section{From ordinary environmentalism to the public environment}

The argument in favor of the conceptual expression of the public environment can be discussed in four points: ordinary environmentalism is based on the alliances between human and nonhuman individuals and groups (Relational logic); these alliances renew the local environment for a range of stakeholders 
(Local spaces); the initiatives impact the ecological quality of the places (Quality of places) and are of a public character (Open to the public).

\section{Relational logic}

Regardless of the municipality concerned and its place in the sample, associations reveal a fascination for the plant and animal world. Communities of living beings identify themselves both individually and collectively by their relationship to the environment, either negatively (with the cockroach for example) or positively (e.g., with the bee or the vine) (Agustina and Beilin 2012). The lives of mushrooms, birds, social insects, etc. give rise to passionate collective commitments focused entirely on fostering local relations and "cohabitation" with living matter. The task involves making place in the life-area for living beings and relations of significant importance that may also be a symbol of a biodiversity under threat (bees, mushrooms, etc.). This relational universe is part of a self-determining and self-qualifying approach that allows communities to define themselves in strong terms: "Place identity originates in people's relationship to the physical, political, and environmental world around them and is also shaped by the experiences and interactions with others" (Anguelovski 2016, as cited in Aygeman et al. 2016: 333). Moreover, animal and vegetable species make it easier to appropriate - and virtually domesticate - urban space. Indeed, it is all about caring for the quality and reproduction of local life through both individual and collective experimentation. So, for example, one respondent who is a member of an agriculture and breeding association in the Seine-Saint-Denis "département" explained their project of planting old vines in Plaine des Vertus as a winegrowing/winemaking experiment for farmers (BU Association based in Villetaneuse, north of Paris).

Many of these associations comprise beekeepers and enlightened amateurs who spend a lot of time observing the behavior of social insects and helping them, as one member in Ivry-Sur-Seine, a poor, essentially urbanized municipality south of Paris, explains: "You have to be aware that we work with wild animals, that they do not know us, that we do not know them, and that when they decide to do that, we can only facilitate conditions. But it's the bees who are the masters, completely." The head of the association draws forms of cohabitation and sharing space with social insects.

The same beekeeper explains that these relationships with nature involve public actors and the transformation of spaces that are adapted to the needs of these insects: "It is also a contract with the local Council, the flowers planted on the ground will be fragrant flowers. (...). Obviously, all of Ivry's planted gardens are visited by our bees." The goal of beekeepers, beyond reintroducing animals into the urban environment, is to share their passion, which is based around their day-to-day experiences of the animal and a renewed sense of identity. The relationships to living beings define a way of being together that relies on communities of living beings that are individually and collectively defined through this relationship, either negatively as with the cockroach (or its scientific name of Blattella germanica), or positively with bees and fungi (Agustina and Beilin 2012).

There are only small numbers of these collectives. For example, in Ivry-sur-Seine, only 30 of the 600 collectives that currently exist directly concern the environment. However, these associations invest the local area and help forge a narrative of an alternative experience-based space of resistance and production. This is clearly the case, for example, with urban beekeeper associations, which deploy complex arrangements to promote beehives and pollination and experiment with processes for protecting bees against the scourge of Asian hornets (Association R based in Les Lilas near Paris).

\section{Local spaces}

The urban spaces invested by public associations - often the case insofar as they are under the auspices of a public authority-or by private associations that are open to the public or to users are underpinned by proximity-based approaches depending on the neighborhood or city and cater to diverse needs in accordance with their specific qualities and functions. These spaces are also proof that a neighborhood, urban block, or more particularly a city, is working properly and help with their identification in social representations and practices. Our enquiries clearly show that these spaces play a key role in how a local community works and in whether feelings of being a citizen are shared or not. The Al Association in the 12th "arrondissement" of Paris is proof of this: "the communal gardens of the 12th arrondissement have specific characteristics depending on the association or the neighborhood in which they are located. Otherwise, here at general municipality level, we have traditionally worked with Relais 59, a social services center near Gare de Lyon rail station. Elsewhere, a diverse range of associations operate. For example, we have just started dealing with a new association for disabled adults that organized a cooking-themed evening in our premises. They came to us because they wanted to organize an event to which parents could come, and the idea worked really well. In fact, I would say that our work with the municipality is focused less on social issues. In gardening, at Aligresse we also have this partnership with the Raoul Follereau association, which looks after physically disabled people. For example, here on Mondays, we don't provide homework support - that will be provided at Relais 59. We hold workshops, etc."

And yet today, we observe that spaces that are open to the public are experiencing a crisis due to public disenchantment with social mix and a move toward more segregated living arrangements and fear or even repulsion regarding ownership of these spaces or safety-related issues. These spaces are seen as derelict rather than "community-based" or common spaces due to their importance in the lives of citizens and their capacity to forge lifestyles (Iaione 2016). (A common good is a resource to which it is difficult to exclude access for potential beneficiaries but for which (over) exploitation diminishes the quantity and quality and potentially prevents others from enjoying the resource (rivalrous and nonexcludable good), unlike a public good whose use by one person does not prevent use by another person (nonrivalrous and nonexcludable good) (Ostrom 1990). The focus is therefore on designing institutions that will enable the resource to be used in a sustainable way.) Their contribution as a common resource, thanks especially to the work of associations in enabling citizens to care for their own city (Bowles and Gintis 2011), helps them enhance their individual and collective capacity to forge reciprocal social cooperation networks based on solidarity.

As such, the common aspect of a resource is less the description of a good (or a space) than a normative claim to use a resource that could otherwise be under exclusive private or public control due to its social value or the utility that such access would generate 
or produce for the community. The ES 93 association at Les Lilas near Paris sheds light on this process with the example of the installation of solar panels: "We target citizens and citizen representatives, meaning at least local authorities, citizens, public and private rooftops, as well as businesses. We don't have any for the moment but I haven't lost hope. The idea is that we provide leverage to help those willing to invest, and this may mean lending or leasing a rooftop. We provide 20-year rooftop leases and, at the end of 20 years, whatever is on the rooftop belongs to the lessee."

However, we note that many associations do not reappropriate these spaces for living beings, plants, or animals that would in consequence transform dereliction into an alliance with the elements of nature and biodiversity. Local authorities promote and showcase this trend, which highlights qualitative appropriation of these spaces and the exercise of local democracy. The R association in Les Lilas bears this out: "I created this association about 6 years ago with another person who knew nothing about beekeeping but really wanted to set up this association. We were helped a lot by the Council who wanted to locate a beehive in Les Lilas because it was the done thing at the time. Hives are appearing on more and more Parisian rooftops and municipal buildings. It was a fashionable thing to do. But I should still express my gratitude to the local council who gave us access to a site and allowed us to place a mobile home there to have a place that we could call our own with a barrier and a few improvements, such as paving and the like. So we couldn't have done it without them." In reality, the task is frequently control and pacification of public space, a task that normally falls to elected representatives. The heads of associations played an intermediary role in enhancing the public space.

\section{Quality of places}

A third observation focuses on the relations forged with nature by the members of these associations as they strive to foster a quality environment in their neighborhood open to everyone in order to boost place-specific effects by enhancing the quality of local relations, e.g., AMAP associations. These days, a quality environment often means renaturalizing spaces. The bulk of respondents create or protect their gardens, natural spaces (residual forests, greenways, waterways, communal or public gardens, beehives, etc.) or living spaces more generally (waste removal, recycling, combating pollution). This does not mean creating a garden for oneself but actually contributing to the public environment in its material dimensions. Incidentally, the relationship between individual and the general interest is one of the reasons cited for involving collectives more effectively in local governance arrangements (Habermas 1992). Relations with living or nonliving matter, qualified in terms of their contribution to a local ecosystem, define the quality of these spaces.

Let's listen to this winemaker from the SainFoins Confederation discussing his vines in Le Perreux, a neighborhood of eastern Paris. "There used to be vines here before. (...) In Le Perreux, there were vines everywhere - it was the vineyard of Nogent. There were slopes everywhere. Here, there was no embankment because in 1850 when the line was built, it was the countryside, and the embankment was created by the line, but further on there are hillsides and vines everywhere (...) When it was created in 2000, the aim of this association was to grow vines, make wine, and create a nice place." The care given to them can influence the transformation of social-ecological systems (Buijs et al. 2016) and also prove to be a significant factor in the relationship at work with the environment (Chan et al. 2016) that seeks to spread throughout the public space, sometimes by showcasing a specific way of life (McClintock 2018). Publicizing "ecological" ways of life helps highlight cities and territories, as borne out by the promotion of the sustainable features of the urban communities of Montreuil (part of Métropole du Grand Paris), Freiburg (southern Germany), or Portland (Oregon, USA), sometimes in terms of tourism or spatial gentrification. As such, the aesthetic qualities of these spaces play a key role in defining the quality of life. This concerns both perceived forms and the invention or creation of environments in the public space. We may say that value becomes the corollary of proximity as well as of density in the relations forged (Borch and Kornberger 2015).

\section{Open to the public}

A fourth remark concerns receiving and opening the spaces concerned to the public or, conversely, the types of public admitted. Welcoming the public is sometimes part of a convention but, more frequently, it is a stakeholder in the project itself. As the VF association based in the 12th arrondissement of Paris explains: "When we arrive, we have to set up the sales counter and get out the cash register. There is everything needed to sell and welcome the public. Everything needed for the house, cleaning, doing the dishes and the garden, take stock of what needs to be sown and what has to be done in the garden, weeding, etc... all the stuff needed to make the garden work. From time to time, our employee organizes team-building initiatives or events for schools. Sometimes, because there are a lot of people and she can't do everything on her own, she calls up a few volunteers and members. We're open to the public and we take visits on the weekend and in the afternoons." The SV association based at Ivry-Sur-Seine near Paris also explains that: "The principle is that the door stays open as long as there is someone inside. It doesn't matter who they are, if they go inside, we must approach them and ask, "are you interested in this? Would you like a visit?" This is one of the basic principles. Sometimes, depending on whether it is a shared, collective or communal garden, the internal/external relationship actually disappears, and this explains the porosity between public and private space and the development of the category of common goods beyond its strict academic interpretation (Baudry et al. 2014).

Ordinary environmentalism is proof of the extension of contractualization arrangements among organizations from civil society to take charge of environment-related activities or spaces. As such, ordinary environmentalism is welcomed by public authorities as a new way of managing neglected public spaces (Erwein and Tollis 2017).

Although we can refer to the public environment from a citizen perspective, the forum for discussion or debate, as well as the concrete space, actually subsumes the expression of public space and takes on new-environmental-dimensions. Taking charge of environmental living conditions that were partially eluded by public authorities in the urban space through the 2000s, is being reflected notably in urban policies to restore spaces to their natural state. 


\section{DISCUSSION}

\section{The forms of a public environment}

How can ordinary environmentalism - made up of this myriad of local initiatives extended in time and space that allow even a modest transformation of the environment (Blanc and Paddeu 2018) - provide a platform for sustainable social - ecological transformations, both individually and collectively, and how can enhanced recognition be provided for such citizen dynamics?

Alliances between human beings and elements of the environment underpin narratives highlighting the attachment of people to places and their dynamics, but also showcase the common construction dynamics of these natural spaces and species in the city that participate in collective activities (gardening, socialization, etc.) and promote the development of "commoning" practices relating to material resources (shared gardens, common leisure activities, collective security, etc.) and/ or immaterial practices (building collective trust, rules of sharing, social networks, companionship, riparian rights, aesthetic quality of spaces, etc.).

According to Foster and Ialone (in press), cities can be considered as commons, but according to the adjusted principles of Ostrom (1990). Thus, these are "built commons that include a collaborative process that leads people who work together to codesign and produce shared goods and services on behalf of the collective. The communities concerned establish themselves as resource protectors in the face of the privatization of spaces, or as "enhancers" of concrete situations of existence" (Hess 2008: 40). The collectives studied within the scope of the CIVIC ACT participate in this dynamic under various conditions in accordance with urban morphology and the local environmental and socioeconomic situation. Admittedly, urban commons are not "natural" resources as understood by Ostrom (1990), but resources to be built in common. In this sense, the process of constructing these commons - sometimes called "commoning" -refers to "a collaborative process of bringing together a wide range of actors that work together to co-design and co-produce shared, common goods and services at different scales. They can be created at the scale of the city, district, neighbourhood or block" (Bollier et al. 2015, Bresnihan and Byrne 2015).

Building these commons even adds to the value of neighborhoods according to the heads of certain associations. In addition, elected officials can be called upon to guarantee the quality of these spaces in the interests of the community through labels, contracts, or charters. The renewal of the Community Land Trust (CLT) in Europe and the USA is evidence of this renewal of "commons" (Kuhne 2015). We may also consider that the question of pooling processes can be placed at the heart of the reformulation of a political horizon (Gibson-Graham et al. 2016). Such a perspective tends to stress the importance of relationships with nature and the individual and the collective environment as "common aesthetics" (Blanc and Benish 2016) and cultural aesthetics (i.e., languages, artistic or ordinary representations, etc.) without which the community would not exist as evidenced by the VBBB Association in the 12th arrondissement of Paris: "I think that the primary goal is to enhance the living environment with a vision that is a little more ecologist - not in the sense of the Green Party but of protecting and respecting the environment."

\section{Elements of theorization}

Rather than debate the public space, this expression, which refers both to a space for debate-transparency of communication between groups from a common cultural background (Habermas 1992) and agonistic confrontation (Mouffe 2007-and to a concrete space emerging from habitat morphology, we wish to discuss the process for building a public environment in common. It is about what surrounds us: a material space made up of environmental forms such as parks and gardens, rivers, and streets as well as environmental narratives, or the ambiances lent to places, between meaning and senses, including air, water, earth, and living organisms, i.e., the social and natural dimensions that characterize the capacity we have to live and to reproduce there, often under public goods (e.g., air quality) or common goods "regimes" (e.g., biodiversity on different scales) (Ostrom 1990). A public environment therefore is an environment that participates in the collective well-being, fulfils a general interest need and contributes to the public service. Our findings also highlight the criteria that must correspond to the initiatives in order to be qualified in terms of public environment: the spaces invested by these initiatives must be considered in socioecosystemic terms and favor the ecologization of social practices; the action initiated must fit into the public space or debate and help to coordinate it; part of the public service mission is assumed by the sponsors of the initiative, and it is possible to refer to a public service concession arrangement. Therefore, the use of the expression "public environment" can enrich the notion of public space by conferring a social and material dimension on debating forums that qualifies an environmental issue in the media and discussion arenas. Lastly, it is a set of dimensions that characterize in a concrete manner what surrounds us and to which our daily activities contribute in a more or less active and intentional way. Conceptualizing the services offered by the network of associations within the public space (social ties, air quality, water quality, communal gardening, and recreational spaces, etc.) in terms of the management of common goods, the goal is to build the dimensions of a quality public environment as a sustainable resource.

This analytical logic is part of a criticism of neoliberal political regimes aimed at regaining political control of urban development and promoting beneficial access to the organic dimensions of urban spaces. The integration of a multiplicity of culturally and politically entrenched agents and practices reflects the ways in which we understand the dynamics of collective action. They are no longer the sole fact of the agents, nor even the product of an inertia proper to a sequence of facts - for example, the dynamics of widening inequalities between the communes or a technological innovation-but the product of material routines, that is, behaviors and dynamics that give meaning to the territories in which they are engaged (Welch and Yates 2018). In his book "The right to the city"(1968-1972,1996), the French philosopher Henri Lefebvre highlighted a necessary reappropriation of urban living arrangements. However, it is clear from local political cultures that rights of access to public decision making or the direct transformation of public spaces are unequally shared. The "commons" movement is part of this reflection on public spaces against the privatization of these same spaces and the individualization of inhabitants as consumers or customers of urban services. But we should not ignore the 
neoliberal impacts of public service concessions on the associative movement (Swyngedouw 2005).

\section{CONCLUSION}

In the first section, we attempted to demonstrate how the findings of our research program CIVIC ACT could justify the use of the expression "public environment." In the second section, we set out elements of theoretical support for the findings of our surveys by referring to research on "commons" and analyzing the conceptual expression of the public environment.

In general, it is important to understand the role of civil society collectives in forging imagery of resistance to the neoliberal order and the invention of localized utopias governed by common practices in the integration of nonEuropean urban populations (Darly and McClintock 2017). However, in lower income communes like Ivry-sur-Seine on the periphery of Paris, the growing importance of civil society environmental collectives could also point to gentrification of urban space by predominantly white middle classes, synonymous with the sidelining or disappearance of people of foreign origin (Bonds and Inwood 2016). At present in Greater Paris, such environmentalism is being promoted by people who mostly belong to intermediate and higher socioprofessional categories (especially senior public servants, intellectuals, and artists), underpinned by a combination of affinity-based social approaches, even though the stakeholder groups are often made up of a small group of people living locally with converging cultural and social resources and affinities in terms of tastes and practices. However, we should note that many collectives are anxious to promote diversity and environmental activism as a means of breaking traditional social ties. This is the case, for example, with shared gardens located in poorer municipalities on the outskirts of cities in which low-income families with diverse origins and political affiliations participate (Association JP in Bobigny, north of Paris), or associations combating nuisances or pollution that provide advice to households who are often in a distressed situation (Association O in Sucy).

Responses to this article can be read online at: http://www.ecologyandsociety.org/issues/responses. php/11166

\section{Acknowledgments:}

The CIVIC ACT survey was part of the interdisciplinary research program "Earth Policies in the Anthropocene era (2014-2018) (Axis 3 Critical zone and urbanization conflict dynamics) supported by Université Sorbonne Paris Cité (USPC) in liaison with LADYSS (laboratoire Dynamiques sociales et recomposition des espaces - UMR 7533 (integrated research unit), a research lab specializing in social dynamics and shifting spatial patterns) and CEVIPOF (Sciences Po's political research unit). I would like to thank first and foremost Flaminia Paddeu, postdoctoral researcher at LADYSS within the scope of this research contract and Senior Lecturer at Universite Paris XIII, who designed the survey that formed the basis for these reflections. Thanks also to Jean Chiche and Diego Antolinos-Basso with whom we devised the research protocol for the CIVIC ACT project (Survey of metropolitan citizen environmentalism). This project was supported by Labex Dynamite whose financial and scientific contribution we are very grateful for. I would like to thank Lindsay Campbell, Michelle Johnson, and Erika Svendsen (USDA Forest Service) for the Franco-American scientific exchanges that we had around the survey. Arthur Capdevielle and Antoine Mailfait, students of the 2ADL Masters program at Université Paris Diderot, as well as Flore Chantraine (Urbanescence), helped with data gathering. We would also like to thank Sarah Irion for her help in retranscribing the interviews.

\section{LITERATURE CITED}

Agustina, I., and R. Beilin. 2012. Community gardens: space for interactions and adaptations. Procedia-Social and Behavioral Sciences 36: 439. https://doi.org/10.1016/j.sbspro.2012.03.048

Agyeman J., and A. Briony. 2003. The role of civic environmentalism in the pursuit of sustainable communities. Journal of Environmental Planning and Management 46(3):345363. https://doi.org/10.1080/0964056032000096901

Agyeman, J., D. Schlosberg, L. Craven, and C. Matthews. 2016. Trends and directions in environmental justice: from inequity to everyday life, community, and just sustainabilities. Annual Review of Environmental Resources 41:321-340. https://doi.org/10.1146/ annurev-environ-110615-090052

Alaimo, S. 2010. Bodily natures: science, environment, and the material self. Indiana University Press, Bloomington, Indiana, USA.

Alaimo, S. 2016. Exposed: environmental politics and pleasures in posthuman times. University of Minnesota Press, Minneapolis, Minnesota, USA. https://doi.org/10.5749/minnesota/9780816621958.001 .0001

Andrews, K., and B. Edwards. 2005. The organizational structure of local environmentalism. Mobilization 10 (2):213-234.

Barad, K. 2007. Meeting the universe halfway: quantum physics and the entanglement of matter and meaning. Duke University Press, Durham, North Carolina, USA. https://doi. org/10.1215/9780822388128

Barad, K. 2016. La grandeur de l'infinitésimal. Nuages de champignons, écologies du néant, et topologies étranges de l'espace-temps matérialisant. Multitudes 65, Dossier Nouveaux Matérialismes: 64-74. https://doi.org/10.3917/mult.065.0064

Barthel, S., C. Folke, and J. Colding. 2010. Social-ecological memory in urban gardens. Retaining the capacity for management of ecosystem services. Global Environmental Change 20:255-265. https://doi.org/10.1016/j.gloenvcha.2010.01.001

Baudry, S., J. Scapino, and E. Rémy. 2014. L'espace public à l'épreuve des jardins collectifs à New York et Paris. Géocarrefour 89(1-2):41-51. https://doi.org/10.4000/geocarrefour.9388

Bennett, J. 2010. Vibrant matter, an ecology of things. Duke University Press, Durham, North Carolina, USA and London, UK.

Blanc, N., and B. Benish. 2016. Form, art, and environment: engaging in sustainability. Routledge, London, UK. https://doi. org/10.4324/9781315660370 
Blanc, N., A. Cannabate, N. Douay, A. Escobar, and F. Paddeu. 2017. Mobilisations environnementales et dynamiques des territoires : le cas de Plaine Commune, communauté d'agglomération d'Ile-de-France. VertigO - la revue électronique en sciences de l'environnement. [online] URL: http://journals. openedition.org/vertigo/18580 https://doi.org/10.4000/vertigo.18580

Blanc, N., and C. Emelianoff, editors. 2008. L'investissement habitant des lieux et milieux de vie : une condition du renouvellement urbain? Étude européenne prospective (France, Pays-Bas, Allemagne, Russie). Rapport de recherche pour le PUCA (Online Urbamet).

Blanc, N., S. Glatron, T. Lamarche, A. Rankovic, and A. Sourdril. 2017. Governance of urban nature. Articulo - Journal of Urban Research, Briefings [online] URL: http://articulo.revues.org/3212

Blanc, N., and F. Paddeu. 2018. L'environnementalisme ordinaire. Transformer l'espace public métropolitain à bas bruit ? EspacesTemps.net, Travaux 05.04.2018 [online] URL: https:// www.espacestemps.net/articles/lenvironnementalisme-ordinairetransformer-lespace-public-metropolitain-a-bas-bruit

Bollier, D., S. Helfrich, and The Heinrich Boll Foundation, 2015. Patterns of commoning.The Commons Strategies Group, Levellers Press, Amherst, Massachusetts, USA.

Bonds, A., and J. Inwood. 2016. Beyond white privilege: geographies of white supremacy and settler colonialism. Progress in Human Geography 40(6):715-733. https://doi.org/10.1177/03$\underline{09132515613166}$

Borch, C., and M. Kornberger. 2015. Introduction to urban commons: rethinking the city. Pages 6-7 in C. Borch and $\mathrm{M}$. Kornberger, editors. Urban commons: rethinking the city, London/ New York. Routledge, Milton Park, UK. https://doi.org/https:// doi.org/10.4324/9781315780597

Bowles, S., and H. Gintis. 2011. A cooperative species. Human reciprocity and its evolution. Princeton University Press, Princenton, New Jersey, USA. https://doi.org/https://doi. org/10.1007/s00712-011-0237-5

Braidotti, R. 2002. Metamorphoses: towards a materialist theory of becoming. Polity Press, Cambridge, UK.

Bresnihan, P., and M. Byrne. 2015. Escape into the city: everyday practices of commoning and the production of urban space in Dublin. Antipode 47:36-54. https://doi.org/10.1111/anti.12105

Brulle, R., H. Turner, J. Carmichael, and C. Jenkins. 2007. Measuring social movement organization populations: a comprehensive census of US environmental movement organizations. Mobilization 12(3):255-270.

Buijs, A. E., J. M. Thomas Mattijssen, A. van der Jagt, B. Ambrose-Oji, E. Andersson, B. H. M. Elands, and M. Steen Møller. 2016. Active citizenship for urban green infrastructure: fostering the diversity and dynamics of citizen contributions through mosaic governance. Current Opinion in Environmental Sustainability 22:1-6. https://doi.org/10.1016/j.cosust.2017.01.002

Cefaï, D. 2009. Comment se mobilise-t-on ? L'apport d'une approche pragmatiste à la sociologie de l'action collective. Sociologie et sociétés 41(2):245-269. https://doi.org/https://doi. org/10.7202/039267ar
Chan, K. M. A., P. Balvanera, K. Benessaiah, M. Chapman, S. Díaz, E. Gómez-Baggethun, R. Gould, N. Hannahs, K. Jax, S. Klain, G. W. Luck, B. Martín-López, B. Muraca, B. Norton, K. Ott, U. Pascual, T. Satterfield, M. Tadaki, J. Taggart, and N. Turner. 2016. Opinion: why protect nature? Rethinking values and the environment. Proceedings of the National Academy of Sciences 113(6):1462-1465. https://doi.org/10.1073/pnas.1525002113

Chapin, F. S., S. R. Carpenter, G. P. Kofinas, C. Folke, N. Abel, W. C. Clark, P. Olsson, D. M. Stafford Smith, B. Walker, O. R. Young, F. Berkes, R. Biggs, J. M. Grove, R. L. Naylor, E. Pinkerton, W. Steffen, and F. J. Swanson. 2010. Ecosystem stewardship: sustainability strategies for a rapidly changing planet. Trends in Ecology and Evolution 25(4):241-249. https:// doi.org/10.1016/j.tree.2009.10.008

Coole, D., and Frost, S. 2010. New materialisms: ontology, agency, and politics. Duke University Press, Durham, Norh Carolina, USA and London,UK. https://doi.org/10.1215/9780822392996

Darly, S. 2012. S'appuyer sur l'éco-pastoralisme urbain pour réaliser le diagnostic des capacités agricoles de la ville : expérimentation en cours à Plaine Commune. VertigO - la revue électronique en sciences de l'environnement Dossier : Agriculture urbaine : aménager et nourrir la ville 12(2):263-269.

Darly, S., P. Marty, and J. Milian. 2013. La « nature en ville» à l'épreuve de la requalification des banlieues. Le cas de Plaine Commune. Métropolitiques 11. [online] URL: http://www. metropolitiques.eu/La-nature-en-ville-a-l-epreuve-de.html

Darly, S., and N. McClintock. 2017. Introduction au agriculture urbaine et ville néolibérale : perspectives critiques venues d'Europe. ACME: An International Journal for Critical Geographies 16(2):224-231.

Emelianoff, C. 2018. Peut-on définir des capabilités collectives dans une perspective de transition énergétique et sociétale? Pages 85-96 in S. Aubin, C. Dartiguepeyrou, and B. Lemoult, editors. Territoires en transition energétique et sociétale. L'Harmattan, Paris, France.

Enqvist, J., L. Campbell, I. Stedman, and E. Svendsen. 2017. Pathways to urban environmental stewardship: sense of place and civic engagement for urban waterfronts. Pages 155-199 in J. Enqvist. Stewardship in an urban world. Civic engagement and human-nature relations in the Anthropocene. Doctoral thesis in Sustainability Science at Stockholm University, Sweden.

Ernwein, M., and C. Tollis. 2017. Produire la ville vivante : le travail des citadins et des non-humains. L'Information géographique 81: 3. https://doi.org/10.3917/lig.813.0013

Fisher, D., L. Campbell, and E. Svendsen. 2012. The organisational structure of urban environmental stewardship. Environmental Politics 21:26-48. https://doi.org/10.1080/096440$\underline{16.2011 .643367}$

Fisher, D., and E. Svendsen. 2014. Hybrid arrangements within the environmental state. Pages 179-190 in S. Lockie, D. Sonnenfeld, and D. Fisher, editors. Routledge international handbook of social and environmental change. Routledge, New York, New York, USA. https://doi.org/10.4324/9780203814550. $\underline{\mathrm{ch} 15}$ 
Folke, C., R. Biggs, A. V. Norström, B. Reyers, and J. Rockström. 2016. Social-ecological resilience and biosphere-based sustainability science. Ecology and Society 21(3): 41. https://doi.org/10.5751/ ES-08748-210341

Folke, C., and L. Gunderson. 2012. Reconnecting to the biosphere: a social-ecological renaissance. Ecology and Society 17(4): 55. https://doi.org/10.5751/ES-05517-170455

Forno, F., and P. R. Graziano. 2014. Sustainable community movement organisations. Journal of Consumer Culture 14(2):139157. https://doi.org/10.1177/1469540514526225

Foster, S. R., and C. Iaione. In press. Ostrom in the city: design principles and practices for the urban commons. In D. Cole, B. Hudson, and J. Rosenbloom, editors. The Routledge handbook of the study of the commons. Routledge, Abingdon, UK. https://doi. org/https://doi.org/10.4324/9781315162782-19

Gibson, K., J. Cameron, and S. Healy. 2016. Commoning as a postcapitalist politics. Pages 192-212 in A. Amin and P. Howell, editors. Releasing the commons: rethinking the futures of the commons. Routledge, London, UK. https://doi.org/https://doi. org/10.4324/9781315673172-12

Habermas, J. 1992. L'espace public, 30 ans après. Quaderni 18:161-191. https://doi.org/10.3406/quad.1992.977

Hess, C. 2008. Mapping the new commons [online] URL: http:// $\underline{\text { www.ssrn.com/abstract }=1356835}$

Iaione, C. 2016. The CO-City: sharing, collaborating, cooperating, and commoning in the city. American Journal of Economics and Sociology 75(2): 415. https://doi.org/10.1111/ ajes. 12145

Krasny, M. E., and K. G. Tidball. 2012. Civic ecology: a pathway for earth stewardship in cities. Frontiers in Ecology and the Environment 10(5):267-273. https://doi.org/10.1890/110230

Kuhne, J. 2015. Notable urban commons around the world. Pages 2158-2172 in D. Bollier, S. Helfrich, and The Heinrich Boll Foundation. Patterns of commoning. The Commons Strategies Group, Levellers Press, Amherst, Massachusetts, USA.

Lefebvre, H. 1996. Writing on cities. Blackwell Publishing, London, UK.

Lepori, M. 2019. Towards a new ecological democracy: a critical evaluation of the deliberation paradigm within green political theory. Environmental Values 94(28):75-88. https://doi. org/10.3197/096327119X15445433913587

McClintock, N. 2018. Cultivating (a) sustainability capital: urban agriculture, ecogentrification, and the uneven valorization of social reproduction. Annals of the American Association of Geographers 108(2):579-590. https://doi.org/10.1080/24694452.2017.1365582

Meyer, J. M. 2015. Engaging the everyday: environmental social criticism and the resonance dilemma. MIT Press, Cambridge, Massachusetts, USA. https://doi.org/10.7551/mitpress/9780262$\underline{028905.001 .0001}$

Meyer, J. M., and J. Kersten, editors. 2016. The greening of everyday life: challenging practices, imagining possibilities. Oxford University Press, Oxford, UK. https://doi.org/10.1093/acprof: oso/9780198758662.001.0001
Mouffe, C. 2007. Artistic activism and agonistic spaces. Art 1 Research. A journal of ideas, contexts and methods 1(2). [online] URL: http://www.artandresearch.org.uk/v1n2/mouffe.html

Ostrom, E. 1990. Governing the commons: the evolution of institutions for collective action. Cambridge University Press, Cambridge, UK.

Paddeu, F. 2017. Agir à l'heure de l'anthropocène. Les quatre familles de l'environnementalisme urbain. L'Information géographique 3(81):32-53. https://doi.org/https://doi.org/10.3917/ lig.813.0032

Petit, V., and B. Guillaume. 2016. Quelle « démocratie écologique » ? Raisons politiques 2016/4(64):49-66. https://doi.org/https:// doi.org/10.3917/rai.064.0049

Rose, N. 1996. The death of the social? Economy and Society 25 (3):327-356.

Schlosberg, D. 2019. From post-materialism to sustainable materialism: the environmental politics of practice-based movements. Environmental Politics https://doi.org/https://doi. org/10.1080/09644016.2019.1587215

Schlosberg, D., and R. Coles. 2016. The new environmentalism of everyday life: sustainability, material flows and movements. Contemporary Political Theory 15(2):160-181. https://doi. org/10.1057/cpt.2015.34

Sirianni, C., and L. Friedland. 2001. Civic innovation in America. Community empowerment, public policy, and the movement for civic renewal. University of California Press, Berkeley, California, USA.

Springer, S. 2016. Fuck neoliberalism. ACME: An International Journal for Critical Geographies 15(2):285-292.

Svendsen, E., and L. Campbell. 2008. Urban ecological stewardship: understanding the structure, function, and network of community-based urban land management. Cities and the Environment 1:1-31. https://doi.org/10.15365/cate.1142008

Swyngedouw, E. 2005. Governance innovation and the citizen. Urban Studies 42(11):1991-2006.

Torres, A. C., S. Nadot, and A.-C. Prévot. 2017. Specificities of French community gardens as environmental stewardships. Ecology and Society 22(3): 28. https://doi.org/10.5751/ ES-09442-220328

Welch, D., and L. Yates. 2018. The practices of collective action: practice theory, sustainability transitions and social change. Journal for the Theory of Social Behaviour 48(3): 288-305. https:// doi.org/10.1111/jtsb.12168

Westley, F. R., O. Tjornbo, L. Schultz, P. Olsson, C. Folke, B. Crona, and Ö. Bodin. 2013. A theory of transformative agency in linked social-ecological systems. Ecology and Society 18(3): 27. https://doi.org/10.5751/ES-05072-180327 